\title{
DEVELOPMENT OF QUALITATIVE PHARMACOGNOSTIC AND HIGH-PERFORMANCE THIN-LAYER CHROMATOGRAPHIC FINGERPRINTING OF MORPHOLOGICAL SIMILAR SPECIES OF GENUS FICUS
}

\author{
AMANDEEP SINGH ${ }^{1,2}$, HAYAT MOHAMMAD MUKHTAR ${ }^{3 *}$, SAURABH SATIJA ${ }^{4}$, MEENU MEHTA $^{4}$ \\ ${ }^{1}$ Department of Pharmaceutical Sciences, I.K. Gujral Punjab Technical University, Kapurthala, Punjab, India. ${ }^{2}$ Department of \\ Pharmacognosy, Khalsa College of Pharmacy, Amritsar, Punjab, India. ${ }^{3}$ Department of Pharmacognosy , Shaheed Bhagat Singh College \\ of Pharmacy, Tarn Taran, Punjab, India. ${ }^{4}$ Department of Department of Pharmacognosy , School of Pharmaceutical Sciences, Lovely \\ Professional University, Phagwara, Punjab, India. Email: amandeepkcp@gmail.com
}

Received: 07 March 2018, Revised and Accepted: 02 May 2018

\begin{abstract}
Objective: Ficus deltoidea (FD) and Ficus benjamina (FB), popularly known as "jack tree/mas cotek" and "pimpri/java fig," respectively, in India and are used in folk medicine to treat the wound, ulcers, diabetes, microbial infections, and inflammatory disorders. Such therapeutic claims have also been justified in the literature by their rich chemical diversity. Both the plant species are morphologically similar and used unauthentically as the traditional medicinal product. Although these plants are sold in the local market by a traditional medicinal healer, we did not find any authenticated data on its quality.
\end{abstract}

Methods: In the present study, quality standards of both the plant drugs have been developed and compared by performing morphological, microscopical, physicochemical, phytochemical, and high-performance thin-layer chromatographic (HPTLC) analysis. using CAMAG Linomat 5 instrument (Kindly delete the bold matter).

Results: It was revealed that both the plant species have similar pharmacognostic features with some differences in type of stomata, presence of marked midrib, arrangement of the cell, cell structures, and meristele. HPTLC data revealed that the primary component in FD leaves (FDL) and FB leaves (FBL) extracts was found at $R_{f} 0.67$ and 0.37 with the respective peak area of $35.61 \%$ and $34.71 \%$. The peaks at $R_{f} 0.17$ and 0.27 can be appeared as the chemical marker to highlight the quality of FDL, whereas peaks at $\mathrm{R}_{\mathrm{f}} 0.87$ and 0.95 can be considered to identify and chemically standardize the FBL.

Conclusion: This study highlighted essential characters which contribute to the standardization, identification, and authentication of plant drugs.

Keywords: Ficus, Standardization, High-performance thin-layer chromatographic, Microscopy, Quality control, Pharmacognostic.

(c) 2018 The Authors. Published by Innovare Academic Sciences Pvt Ltd. This is an open access article under the CC BY license (http://creativecommons. org/licenses/by/4. 0/) DOI: http://dx.doi.org/10.22159/ajpcr.2018.v11i7.25672

\section{INTRODUCTION}

Quality control of medicinal plant can be understood as the unique approach to confirm and document the identity, purity, biochemical quality, and respective quantity of various biochemicals present in raw material by following pharmacognostic, physicochemical, and phytochemical strategies. Development of qualitative and quantitative data of medicinal plants is considered to be of utmost importance because of similarity in phenotypic and chemotypic characters of the different plants either belonging to same or different genus. Genus "Ficus" (Moraceae) comprises of approximately 800 species globally, and of these, 115 species are distributed in India [1]. Several members of this genus were employed as one of the economical sources of medicine because of same or different genus rich chemical diversity [2-5]. The therapeutic and chemical potential of only of its species was extensively explored and reported in the literature. Owing to the morphological, biochemical, and pharmacological similarities among most of the Ficus species, this is understudied genus in modern pharmacognosy. It was also found in the literature that only some morphological, microscopical, and physical parameters were observed which may be considered inappropriate to identify some similar species of ficus [6-9].

Ficus deltoidea (FD) and F. benjamina (FB) are two morphologically similar perennial trees; grown up to the height of 4-8 m; widely distributed in the plain area of India, Southeast Asia, Malaysia, and Northern Australia. FD and FB are commonly known as ficus mixed and Benjamin's fig/Java fig/Pimpri/weeping fig, respectively, in India [10]. The entire plant parts of both the trees were reported as the drug in traditional medicinal systems. Moreover, the leaves of both the FD and FB were considered in various ethnopharmacological claims. They were reported to have wound healing property, and their decoction was applied on the ulcers with oil.

Further, the ethnopharmacology of FD leaves (FDL) claimed that its decoction is used in the treatment and management of diabetes, menstrual cycle and is also considered as the natural tonic to strengthen the uterine and vaginal muscles after delivery. Preclinical studies on FDL indicated its promising anticancer [11], antidiabetic [12], antiinflammatory [13], and significant wound healing capacities [14]. The presence of wide range of chemical compounds such as vitexin, isovitexin, rutin, quercetin, and naringenin is also considered as an important factor to accept the ethnopharmacological claims and modern pharmacological studies $[15,16]$. On the other hand, FB leaves (FBL) were also considered as folklore medicine in the treatment of various skin and respiratory disorders [17]. The leaves and bark of FBL are used indigenously as an insect repellant and in the treatment of malaria. Various authors had successfully documented the scientific reasons for these ethnopharmacological claims by extensively exploring the pharmacological profile and chemical diversity of FBL [18-23].

Despite the extensive use of both these plants in various research institutes for their traditional significance, there is no such report yet available which defines their identity and authenticity. Hence, an attempt has been made to develop the standard pharmacognostic and phytochemical data of the raw form of these plant drugs following the WHO prescribed protocol. 


\section{METHODS}

\section{Plant material}

Fresh leaves of both the plants were collected from the botanical garden of Khalsa College Amritsar, India, in February 2016. Our team members identified specimens, and their taxonomical identification and authentication was done by senior taxonomist Prof. Parveen Kumar Ahuja, Faculty of Life Sciences, Khalsa University, Amritsar, India. Voucher specimen LSKU/001-18022017 was deposited at the Museum of Khalsa College of Pharmacy, Amritsar. The collected plant specimens were washed with water to remove dirt particles from their surface and then kept at room temperature until completely dried. The dried leaves were ground to get a coarse powder.

\section{Morphology, microscopy, and histochemical study}

The plants leave sample were evaluated for its color, odour, shape, texture, type, arrangement, and size in the morphological study. Microscopic studies were performed to determine the surface characters, leaf constants, and histochemical characters. Chemomicroscopy studies were carried out to understand the behavior of cells or tissue with different chemicals or stains and help us in determining the nature, type, and composition of a cell and their cell wall. Microscopic transverse section cutting of leaves was done by freehand sectioning method. Fine sections were made cleared with chloral hydrate solution and then stained with the freshly prepared phloroglucinol solution in dilute hydrochloric acid (1:1) and mounted in glycerin [7]. Photomicrographs of microscopic sections were captured with the help of Olympus microscope fitted with the camera using the software.

\section{Physicochemical study}

Physicochemical parameters such as moisture content, ash value, alcohol soluble and water-soluble extractive value, and fluorescence analysis were observed by standard methods as described in the literature [24].

\section{Phytochemical study}

The dried powders $(100 \mathrm{~g})$ of both leaves were macerated with $80 \%$ ethanol $(400 \mathrm{ml})$ for $72 \mathrm{~h}$ at room temperature. The filtered crude extracts were examined for preliminary phytochemical and thin-layer chromatographic studies as per standard protocol mentioned in the literature [24].

\section{High-performance thin-layer chromatographic (HPTLC) investigations}

HPTLC fingerprinting of crude hydroalcoholic extracts of both FDL and FBL was carried out using CAMAG Linomat 5 instrument equipped with a sample applicator device, Camag twin trough chamber, Camag TLC scanner, and integration software (Wincats). Crude hydroalcoholic extracts were lyophilized and redissolved in HPLC grade methanol to yield a drug sample of $15 \mu \mathrm{l}$ each. Each spot of $2 \mu \mathrm{l}$ was applied in different tracks at a distance of $16 \mathrm{~mm}$ on pre-coated silica gel $60 \mathrm{~F}_{254}$ plates, and plates were then allowed to run in solvent system ethyl acetate:formic acid:acetic acid:water (7:3:1.1:1.1). The plates were scanned at $254 \mathrm{~nm}$ for identifying the prominent peaks.

\section{RESULTS AND DISCUSSIONS}

\section{Morphology and microscopy}

Morphology and microscopy of FDL and FBL were successfully explored and shown in Fig. 1.

It was observed that both the plants are morphologically similar and have an average height of 5-7 $\mathrm{m}$. The leaves of both FD and FB are simple, entire, petiolate, dark green, and alternate phyllotaxy. FDL was 3-6 cm in length and 2-3 cm in width and elliptical or oval in shape with mucronate apex; forked midrib was centrally running through the leaf blade from its base to apex giving off lateral veins in reticulate venation pattern. FBL was 5-7 cm in length and $2 \mathrm{~cm}$ in width; elliptical or oval in shape with acuminate apex; midrib was not protruding on leaf blade pinnate reticulate venation.

Surface characteristic of both FDL and FBL was successfully explored and shown in Fig. 2.

It was clearly observed that stomata density was higher in FDL comparative to FBL along with thick forked midrib and reticulate venation in both the plant samples. FDL and FBL showed different types of stomata such as diacytic and paracytic, respectively, which distinguished them from each other.

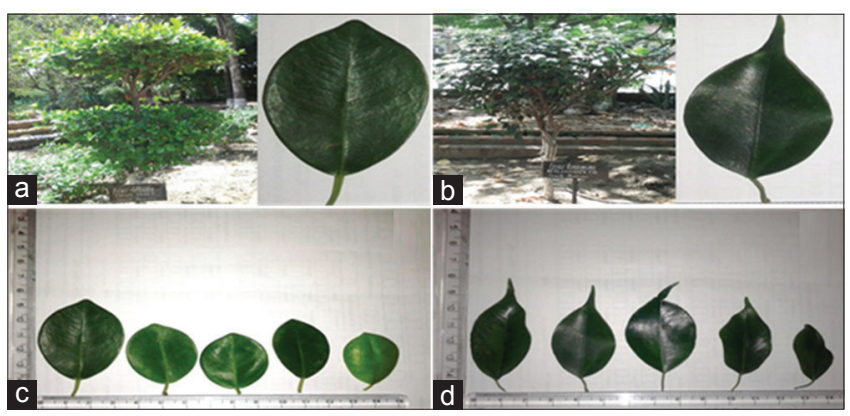

Fig. 1: Morphology of Ficus deltoidea leaves (FDL) and Ficus benjamina leaves (FBL), (a) entire plant of FD and FDL, (b) entire plant of FB and FBL, (c and d) size determination of FDL and FBL

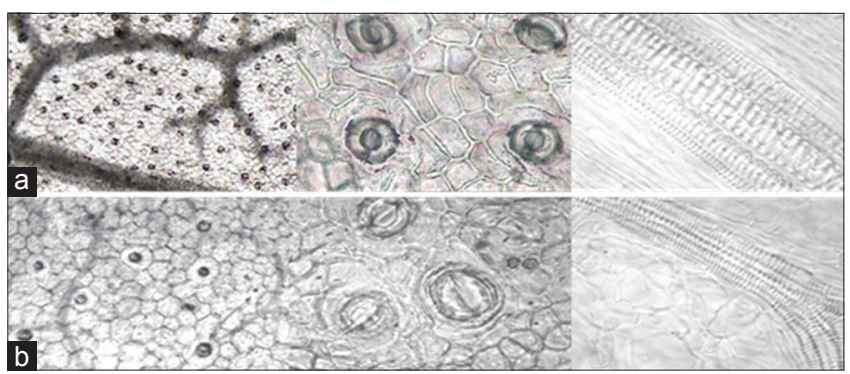

Fig. 2: Surface view of Ficus deltoidea leaves (FDL) and Ficus benjamina leaves (FBL), (a) reticulate venation, diacytic stomata, and forked midrib in FDL, (b) reticulate venation, paracytic stomata, and centralized midrib in FBL
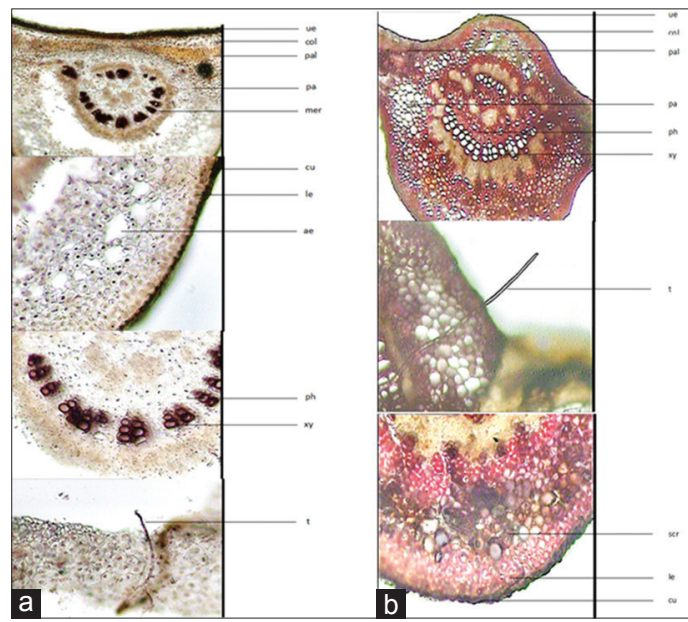

Fig. 3: Microscopy of (a) Ficus deltoidea leaves (FDL) and (b) Ficus benjamina leaves (FBL) (col - collenchyma, cu - cuticle, le - lower epidermis, mer - meristele, pa - parenchyma, pal - palisade, ph - phloem, scr - sclerenchyma, $\mathrm{t}$ - trichomes, ue - upper epidermis, and xy - xylem) 
Transverse section cutting of both FDL and FBL was successfully observed and shown in Fig. 3.

T.S. of FDL passing through midrib is dorsiventral in nature, broadly convex on the lower side, slightly centrally depressed on an upper side, and shows an arc of centrally located broad meristele and rudimentary vascular strands lying above it. Meristele embedded in parenchymatous ground tissue and consists of 10-14 rows of radially running 2-3 xylem vessels becoming small in size gradually. It showed a layer of upper and lower epidermis covered with cuticle, transverse with a diacytic type of stomata. Underneath, both the epidermis of midrib lie 3-5 layers of collenchymatous cells followed by pitted parenchymatous ground tissue embedded with marked aerenchymatous cells toward lower epidermis. TS of FBL passing through midrib is dorsiventral, convex at the bottom side, slightly elevated at the upper side, and showed an arc of centrally located broad meristele. Detailed TS of FBL leaf passing through midrib shows a layer of upper and lower epidermis covered with cuticle and embedded with paracytic stomata; underneath, both the epidermis of midrib lie 2-3 layers of lignified collenchymas tissue, the remaining tissue being parenchymatous embedded with meristele, consisting of 18-20 rows of radially arranged $2-3$ xylem vessels becoming small in size gradually.
The measurement of quantitative microscopy data revealed that stomatal density and other leaf constants determined in FDL were higher in range comparative to FBL as indicated in Table 1.

\section{Physicochemical parameters}

Different physicochemical parameters were evaluated, and their values are shown in Table 2 .

The moisture content was important to determine since an excess of moisture in herbal material promotes the hydrolysis and growth of microbes. The percentage of total moisture content of fresh FDL and FBL was found to be 13.2 and 11.5 , respectively. The extractable

Table 1: Quantitative microscopy of plant species

\begin{tabular}{lll}
\hline \multirow{2}{*}{ Parameter } & \multicolumn{2}{l}{ Quantitative value $\left(\right.$ range $\left./ \mathbf{m m}^{2}\right)$} \\
\cline { 2 - 3 } & FDL & FBL \\
\hline Stomatal index & $11 \pm 1$ & $9 \pm 1$ \\
Vein islet number & $9 \pm 1$ & $6 \pm 1$ \\
Vein termination number & $10 \pm 1$ & $7 \pm 1$ \\
\hline
\end{tabular}

FDL: Ficus deltoidea leaves, FBL: Ficus benjamina leaves

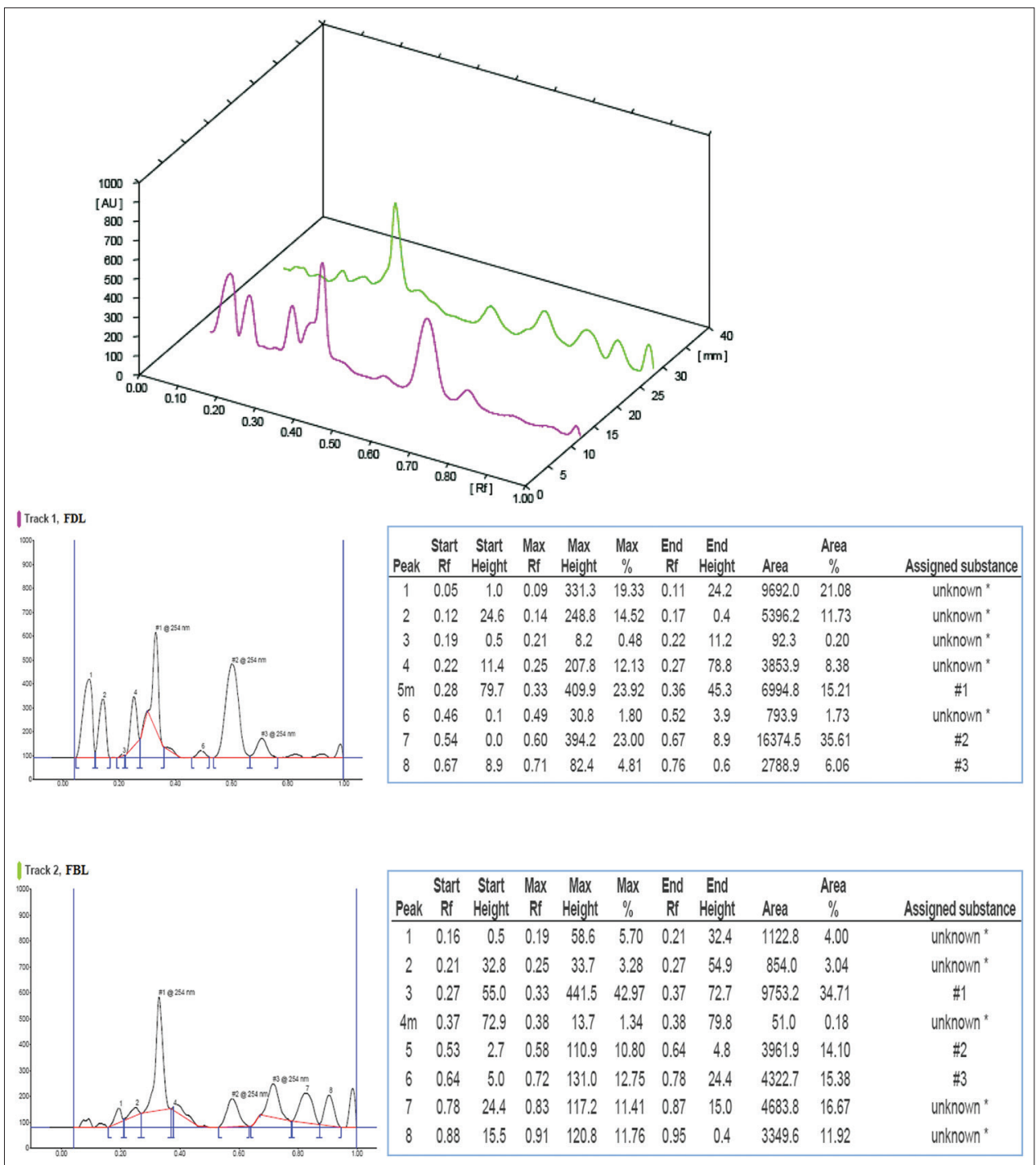

Fig. 4: High-performance thin-layer chromatographic fingerprint of plant leaves extract and their $\mathbf{R}_{\mathrm{f}}$ value 
matter in plant samples was successfully determined which describes the amount or type of plant constituents extracted with different solvents. Water-soluble and alcohol-soluble extractive values were found comparatively higher in the FDL than FBL which indicates the presence of polar constituents in high quantity in both the plant leaves. The ash value was determined to establish the quality and purity of crude plant materials and to remove all traces of organic matter which may otherwise interfere with an analytical determination. For this, a sample was placed in the muffle furnace for a long period at high temperature so that complete combustion of the sample occurs. The total ash determined in FDL and FBL was $8.2 \% \mathrm{w} / \mathrm{w}$ and $11.7 \% \mathrm{w} / \mathrm{w}$, respectively, and comparative to total ash values, the high percentage of acid insoluble ash was determined in FBL which indicates the presence of silicate material in relatively higher amount than FDL

The fluorescence characters of dried powdered plant drugs and acid- or base-treated plant drugs were determined under visible light, short, and long ultraviolet and are presented in Table 3.

These characteristic color properties could be used as a standard for the identification and authentication of the FDL and FBL in its crude form.

Phytochemical investigations

The preliminary phytochemical analysis of crude hydroalcoholic extracts of FDL and FBL revealed the presence of most of the polar compounds

Table 2: Physiochemical characteristics of plant species

\begin{tabular}{lll}
\hline Parameter & FDL $(\% \mathbf{w} / \mathbf{w})$ & FBL $(\% \mathbf{w} / \mathbf{w})$ \\
\hline Total ash & $8.2 \pm 0.21$ & $11.7 \pm 0.18$ \\
Acid-insoluble ash & $0.9 \pm 0.14$ & $1.8 \pm 0.22$ \\
Water-soluble ash & $1.7 \pm 0.14$ & $2.3 \pm 0.08$ \\
Moisture content & $13.2 \pm 0.13$ & $11.5 \pm 0.21$ \\
Alcohol-soluble extractive value & $8.35 \pm 0.17$ & $6.72 \pm 0.12$ \\
Water-soluble extractive value & $16.28 \pm 0.31$ & $14.20 \pm 0.08$ \\
\hline FDL Ficus deltoidea leaves, FBL- Ficus benjamina leaves &
\end{tabular}

such as carbohydrates, glycosides, saponins, phytosterols, phenols, tannins, and flavonoids (Table 4). The data indicated the presence of all the above-listed chemical classes in FDL extract. However, flavonoids, phenols, and saponins are absent in case of FBL extract. This result indicates that abundant quantity of polar compounds could be present in FDL and FBL

\section{HPTLC study}

The HPTLC chromatographic fingerprinting of crude methanolic extracts of both FDL and FBL was developed under the chromatographic conditions described above. Fig. 4 shows the HPTLC fingerprinting of FDL and FBL, numbers of peaks, their $\mathrm{R}_{\mathrm{f}}$ values, and percentage area occupied by individual peaks of both FDL and FBL crude extracts. Three significant peaks at $R_{f} 0.36,0.67$, and 0.76 in both the FDL and FBL extracts were found common. The principal component found in FDL and FBL extracts was found at $R_{f} 0.67$ and 0.37 with the respective peak area of $35.61 \%$ and $34.71 \%$. The peaks at $\mathrm{R}_{\mathrm{f}} 0.17$ and 0.27 can be considered as unique identity or chemical marker to highlight the quality of FDL, whereas peaks at $\mathrm{R}_{\mathrm{f}} 0.87$ and 0.95 can be considered to identify the FBL and chemical standardization of FB crude drug. The process of isolation and identification of these components is under process and will soon come up with a refined picture.

\section{CONCLUSIONS}

Quality standards of FDL and FBL were developed, and significant differences were observed in morphology, microscopy, pharmacognosy, and HPTLC data. Leaves of both the medicinal plants displayed variation in size, shape, and their surface characters, whereas microscopic examination distinguished them by variation in the type of stomata, the presence of marked midrib, the arrangement of the cell, cell structures, and meristele. The presence of aerenchymatous cells in FDL has marked its identity which was utterly absent in FBL. The type, content of organic matter, and the distribution of various components in plant leaves were concluded from physicochemical and fluorescence analysis. Although both FDL and FBL contain almost same phytochemical organic substances, their HPTLC fingerprints showed the presence of some

Table 3: Fluorescence characteristics of ficus species with different reagents

\begin{tabular}{|c|c|c|c|c|c|c|}
\hline \multirow[t]{3}{*}{ Treatment } & \multicolumn{6}{|c|}{ Fluorescence characters } \\
\hline & \multicolumn{3}{|l|}{ FDL } & \multicolumn{3}{|l|}{ FBL } \\
\hline & Visible light & $\begin{array}{l}\text { Short UV } \\
(254 \mathrm{~nm})\end{array}$ & $\begin{array}{l}\text { Long UV } \\
\text { (366 nm) }\end{array}$ & Visible light & $\begin{array}{l}\text { Short UV } \\
(254 \mathrm{~nm})\end{array}$ & $\begin{array}{l}\text { Long UV } \\
\text { (366 nm) }\end{array}$ \\
\hline Dried Powder as such & Greenish brown & Dark green & Brownish & Greenish brown & Dark green & Brownish \\
\hline Sodium hydroxide & Dark green & Dark green & Orange brown & Dark green & Dull green & Orange \\
\hline Hydrochloric acid & Dull green & Green & Dull green & Dull green & Greenish yellow & Brown \\
\hline Nitric acid & Brown & Dull Green & Dull yellow & Dull brown & Greenish yellow & Brownish yellow \\
\hline Distilled water & Dark green & Green & Greenish brown & dark green & greenish brown & Brownish yellow \\
\hline
\end{tabular}

FDL: Ficus deltoidea leaves, FBL: Ficus benjamina leaves, UV: Ultraviolet

Table 4: Phytochemical screening of FDL and FBL plant extracts

\begin{tabular}{|c|c|c|c|c|}
\hline S. No & Chemical constituent & Tests & FDL MeOH & FBL MeOH \\
\hline \multirow[t]{3}{*}{1} & Carbohydrates & Molisch's test & + & + \\
\hline & & Benedict's test & + & + \\
\hline & & Fehling's test & + & + \\
\hline \multirow[t]{2}{*}{2} & Glycosides & Modified Borntrager's test & +++ & ++ \\
\hline & & Legal test & ++ & ++ \\
\hline 3 & Saponins & Froth test & ++ & - \\
\hline 4 & Phytosterols & Salkowski's test & +++ & + \\
\hline 6 & Phenols & Ferric chloride test & ++ & - \\
\hline 7 & Tannins & Gelatin test & ++ & ++ \\
\hline \multirow[t]{2}{*}{8} & Flavonoids & Alkaline reagent test & ++ & - \\
\hline & & Lead acetate & + & + \\
\hline
\end{tabular}

FDL: Ficus deltoidea leaves, FBL: Ficus benjamina leaves 
distinguishing phytocomponents in them which could be considered as the vital tool for quality analysis, identification, and standardization of individual plant drugs.

\section{ACKNOWLEDGMENTS}

The authors wish to thank Dr. Kirandeep Kaur, Incharge botanical garden, Khalsa College, Amritsar, for providing the plant samples. We also acknowledge Dr. R.K. Dhawan, Director, Khalsa College of Pharmacy, Amritsar, Punjab, for providing adequate laboratory facilities required for the presented work.

\section{AUTHOR'S CONTRIBUTIONS}

All authors have equal contribution.

\section{CONFLICTS OF INTEREST}

The authors declare that there is no conflict of interests regarding the publication of this paper.

\section{REFERENCES}

1. Ephraim PL, Helena MP. Figs: The Genus Ficus, Traditonal Herbal Medicines for Modern Times. Vol. 9. Boca Raton: CRC Press; 2011.

2. Sindhu RK, Arora S. Therapeutic effect of ficus lacor aerial roots of various fractions on adjuvant-induced arthritic rats. ISRN Pharmacol 2013;2013:1-8.

3. Shittu I, Emmanuel A, Nok AJ. Antimalaria effect of the ethanolic stem bark extracts of Ficus platyphylla. J Parasitol Res 2011;2011:618209.

4. Ravichandiran V, Manivannan S. Wound healing potential of transdermal patches containing bioactive fraction from the bark of Ficus racemosa. Int J Pharm Pharm Sci 2015;7:326-32.

5. Ragasa CY, Torres OB, Shen C, Bernardo LO, Mandia EH, Tsai P. Chemical constituents of Ficus linearifolia and Ficus triangularis. Chem Nat Compd 2014;50:152-3.

6. Patil V, Pimprikar R, Patil V. Pharmacognosticcal studies and evaluation of antiinflammatory activity of Ficus bengalensis Linn. J Young Pharm 2009; $1: 49$

7. Babu K, Gokul SS, Rai S. Comparative pharmacognostic studies on the barks of four Ficus species. Turk J Bot 2010;34:215-24.

8. Ahmed F, Urooj A. Pharmacognostical studies on Ficus racemosa stem bark. Pharmacog J 2011;3:19-24.

9. Semwal A, Kumar R, Teotia UV, Singh R. Development of quality control parameters for the standardization of bark of Ficus benghalensis Linn. J Acute Dis 2013;2:296-9.
10. Corner EJ. Philosophical transactions of the royal society of London. B Biol Sci 1969;256:281-17.

11. Oh MJ, Hamid AM, Ngadiran S, Seo YK, Sarmidi MR, Park, CS. Ficus deltoidea (Mas cotek) extract exerted anti-melanogenic activity by preventing tyrosinase activity in vitro and by suppressing tyrosinase gene expression in B16F1 melanoma cells. Arch Dermatol Res 2011;303:161-70.

12. Adam Z, Khamis S, Ismail A, Hamid M. Ficus deltoidea: A potential alternative medicine for diabetes mellitus. Evid Based Complement Alternat Med 2012;2012:1-10.

13. Zakaria ZA, Hussain MK, Mohamad AS, Abdullah FC, Sulaiman MR. Anti-inflammatory activity of the aqueous extract of Ficus deltoidea. Biol Res Nurs 2012;14:1-8.

14. Abdulla MA, Ahmed KA, Luhoom FM. Role of Ficus deltoidea extract in the enhancement of wound healing in experimental rats. Biomed Res 2010;21:241-5.

15. Choo CY, Sulong NY, Man F, Wong TW. Vitexin and isovitexin from the leaves of Ficus deltoidea with in-vivo $\alpha$-glucosidase inhibition. J Ethnopharmacol 2012;142:776-81.

16. Salem MZ, Salem AZ, Camacho LM, Ali HM. Antimicrobial activities and phytochemical composition of extracts of Ficus species: An overview. Afr J Microbiol Res 2013;7:4207-19.

17. Chetty CM, Sirisha N, Sreenivasulu M, Sangeeta K. Antioxidant properties of Ficus species-a review. Int J Pharm Tech Res 2010;2:2174-82.

18. Simo CC, Kouam SF, Poumale HM, Simo IK, Ngadjui BT, Green IR, et al. Benjaminamide: A new ceramide and other compounds from the twigs of Ficus benjamina (Moraceae). Biochem Syst Ecol 2008;36:23-43.

19. Parveen M, Ghalib RM, Mehdi SH, Mattu RU, Ali M. A novel antimicrobial triterpenic acid from the leaves of Ficus benjamina (var. comosa). J Saudi Chem Soc 2009;13:287-90.

20. Almahyl HA, Rabmanj M. The Chemical constituents of Ficus benjamina Linn and their biological activities. Pertanika J Sci Technol 2003;11:73-81

21. Hasto S, Mora E, Utami R, Yulis LU. Sub-chronic toxicity of Ficus benjamina Linn leaves ethanol extract on the liver function of white mice. Proced Chem 2014;13:204-8

22. Imran M, Rasool N, Rizwan K, Zubair M, Riaz M, Zia UH, et al. Chemical composition and biological studies of Ficus benjamina. Chem Cent J 2014;8:1-10.

23. Novelli S, Lorena C, Antonella C. Identification of alkaloid's profile in Ficus benjamina leaves extracts with higher antioxidant power. Am J Plant Sci 2014;5:4029-39.

24. Mallya R, Bhitre MJ. Pharmacognostic standardisation and chromatographic fingerprinting of leaves and fruits of Zanthoxylum rhetsa. Int J Pharm Pharm Sci 2018;10:101-4. 